\title{
Imágenes resistentes. Temáticas, narrativas y estéticas del otro cine español
}

Sergio Cobo Durán, Samuel Neftalí Fernández Pichel, Alberto Hermida. Sevilla, Instituto de la Cultura y las Artes de Sevilla, 2016. 198 páginas.

Reseña por Almudena Mata Núñez

http://dx.doi.org/10.12795/AdMIRA.2017.01.11

La segunda década del siglo XXI ha sido testigo del nacimiento de una nueva forma de expresión cinematográfica en España. Desde los márgenes de la industria tradicional, un nutrido grupo de jóvenes directores se sirve de la innovación formal y temática, la experimentación visual, la hibridación de géneros, el posicionamiento político y la libertad creativa favorecida por la escasa financiación para crear una nueva forma de producción. La aparición de nuevos referentes es, junto a la instauración de un circuito de venta alternativo, una pieza clave para entender el llamado otro cine español que explora la ruptura de los cánones clásicos. Profundamente afectado por el contexto de crisis social, política y económica, este otro cine surge como una tendencia ecléctica capaz de atraer la atención de críticos, programadores y un selecto público.

En este contexto, los festivales de cine adquieren una notable importancia como primera ventana de exhibición de estas obras establecidas en la periferia. Es así como, en el marco del Festival de Cine Europeo de Sevilla (SEFF), surge en 2013 la sección Resistencias, en la que compiten los autores de este cine más combativo e independiente. De este apartado del SEFF se nutre Imágenes resistentes. Temáticas, narrativas y estéticas del otro cine español, una exhaustiva obra que estudia en profundidad un corpus de películas insertas en la corriente del cine en los márgenes. El volumen, elaborado por Sergio Cobo Durán, Samuel Neftalí Fernández Pichel y Alberto Hermida, ahonda, a través de una detallada investigación, en las características que distinguen al otro cine español.

El libro comienza de la mano de Alejandro Díaz Castaño, jefe de programación del Festival de Cine Europeo de Sevilla, quien se encarga en el prólogo de esclarecer el papel de los festivales como medios capaces de otorgar visibilidad a una serie de películas que de otro modo no podrían alcanzar al público y la crítica, al no disponer de 
los recursos e infraestructuras necesarias para realizar cuantiosas inversiones en publicidad.

A continuación, el grueso de la obra se divide en dos bloques diferenciados. De un lado, un conjunto de ensayos que analizan minuciosamente los rasgos distintivos del cine resistente, de otro, una recopilación de entrevistas a varios de los directores que representan esta corriente. La investigación va precedida de una pormenorizada introducción de mano de los autores, la cual estructura la escena del cine español contemporáneo, trazando un recorrido por la aparición del otro cine a la vez que pretende definir el concepto de resistencia cinematográfica en las múltiples posibilidades que ofrece el sector audiovisual. La delimitación del término se concibe, en parte, desde de las opiniones de los propios directores, quienes señalan como características de este cine la oposición a la industria tradicional, la experimentación artística y el compromiso político a través de la participación activa del público.

En este primer apartado se realiza, por tanto, una reivindicación de los márgenes cinematográficos como creación de un nuevo espacio audiovisual contrario al de consumo masivo y de producción industrial institucionalizada. Se trata de la generación de un horizonte interesado en proporcionar visibilidad al otro cine, que responde a una forma concreta de percibir el país según la posición sociocultural y económica de los realizadores. El acercamiento al concepto de resistencia marca aquí el camino que seguirá el libro, pues la definición del término será la columna que vertebre el conjunto del texto.

Por su parte, el primer bloque del escrito comienza propiamente con el ensayo Imágenes e imaginarios de un cine (otro), en el que Samuel Neftalí Fernández Pichel plantea un recorrido a través de la influencia del trauma como ruptura y efecto psicológico de desestabilización de los elementos simbólicos. El factor emotivo que realza el dolor y la imposibilidad de dominar el curso de lo real se presenta clave en la búsqueda de nuevos medios de representación ante la disolución de los centros de sentido y el surgimiento de nuevas preocupaciones. Se asiste, de esta forma, a la formación de nuevas construcciones visuales, sociales y simbólicas que permiten reconocer la realidad ante la disgregación del imaginario histórico, lo que realza el papel de la memoria y la necesidad de una revisión continua de la tradición. La relación entre espacios e identidades y la tendencia al tránsito, el desarraigo y lo 
efímero serán, también, puntos a tener en cuenta en esta corriente caracterizada por el desplazamiento y la genealogía, que encajan con el ánimo reconstructivo del otro cine.

Seguidamente, Sergio Cobo Durán lleva a cabo un detallado análisis narrativo que abarca tanto el cine documental como el de ficción. En Narrativas de resistencia. Cómo se estructura la periferia, se plantea el paradigma del otro cine al margen de las estructuras clásicas, gracias a una mayor experimentación por las posibilidades que permite el bajo coste de las producciones. Pese a la variedad de recursos que se encuentran en las películas resistentes, el autor distingue la presencia de ciertos elementos recurrentes que identifican esta tendencia. La preferencia por localizar la acción en las calles de la ciudad y los ambientes urbanos en general se presenta como una presencia imprescindible en la narración en tanto que establece las relaciones de los personajes con el entorno. Junto a ello, la usual aparición del propio director en el relato con referencias biográficas en primera persona hacen del otro cine uno de un alto compromiso político en el contexto actual. La doble disposición de la temporalidad mediante el uso de la anacronía y la intertextualidad son igualmente factores constantes, así como la fragmentariedad estructural y la predilección por la focalización subjetiva o interna, lo que, en suma, permite trazar líneas comunes en las fórmulas narrativas de un cine que apuesta por la participación activa del espectador.

Por último, el primer bloque se cierra con un acercamiento teórico-analítico y un enfoque formal sobre la estética del otro cine. En La pluralidad estética y formal de otro cine posible: Identidades propias y lugares comunes, Alberto Hermida indaga sobre la experimentación visual y formal propiciadas, principalmente, por las condiciones de bajo presupuesto en las que se desarrollan las producciones, además de por la multiplicidad de estilos individuales. La libertad creativa que destilan las películas analizadas se refleja, en primer lugar, a nivel de rodaje y puesta en escena con amplias posibilidades de tratamiento de la imagen, desde la presentación descuidada al estudio de cada detalle. La preferencia por los espacios naturales frente a los decorados destaca por su parte el protagonismo del espacio fílmico en unos metrajes condicionados por la heterogeneidad de formatos, códigos y dispositivos tecnológicos para la captación de la imagen. De la misma manera, el montaje cobra especial importancia en la creación de significado, ya sea por su uso artístico o por la construcción secuencial en la que prevalece la visión propia del director. 
De otro lado, la segunda parte del libro se centra en la opinión personal sobre el concepto de otro cine de un grupo de cineastas participantes en la sección Resistencias del Festival de Cine Europeo de Sevilla en el año 2015. Luis Aller, Ramón Lluís Bande, Miguel Ángel Blanca, Eloy Domínguez Serén, Mauro Herce, Pablo Hernando, Sergio Oksman, Guillermo Peydró y Víctor Hugo Seoane serán los encargados de aportar sus propias concepciones del concepto de resistencia como etiqueta que vincula sus obras.

En definitiva, Imágenes resistentes. Temáticas, narrativas y estéticas del otro cine español, se articula como un profundo estudio capaz de delimitar las bases que caracterizan a esa nueva voz cinematográfica que nace desde los extremos de la industria como respuesta a un contexto de crisis. El volumen invita, sin duda, a sumergirse en el otro cine, descrito con precisión desde cada una de las ópticas audiovisuales posibles, lo que convierte el libro en una lectura obligatoria para comprender la creación cinematográfica en el panorama actual. 